\title{
A strip-tease act conducted in pink limelight: Salvador Dali, George Orwell, and the construction of a surreal/ist self
}

\author{
Daniella Sanader* \\ *This manuscript was prepared under the supervision of Professor Sally Hickson, \\ School of Fine Art and Music, College of Arts, \\ University of Guelph, Guelph, Ontario, Canada
}

\begin{abstract}
Within this paper I examine the relationship between Salvador Dali's grandiose autobiography, The Secret Life of Salvador Dali, and a critical article by George Orwell entitled "Benefit of Clergy: Some Notes on Salvador Dali." Through a consideration of these two related texts, this paper will focus on the methods through which Dali constructs his artistic persona - in a way that emphasizes his identity as contingent, de-centered and multidimensional. By analyzing several aspects of Dali's public life, including autobiographical writings, paintings and television appearances, I will also consider his motivations as both Surrealist and economic in inclination. Ultimately, I develop an understanding of Dali as a textual, historicized entity; one that allows me to explore the ways in which artistic identity is constructed for public consumption and entertainment.
\end{abstract}

"Dali is even by his own diagnosis narcissistic, and his autobiography is simply a strip-tease act conducted in pink limelight.” - George Orwell, "Benefit of Clergy: Some Notes on Salvador Dali”.

"One thing, at least, is certain: everything, absolutely everything, that I shall say here is entirely and exclusively my fault.” - Salvador Dali, "The Secret Life of Salvador Dali”.

"A $\mathrm{t}$ the age of six I wanted to be a cook. At seven I wanted to be Napoleon. And my ambition has been growing steadily ever since [1].” These are fitting words to introduce the autobiography of a man who spent his entire artistic career simultaneously fashioning himself into a myriad of identities: from genius, to madman, to commodity, to Surreal/ist. The colourful story of Salvador Dali is a fascinating example of the development of a twentiethcentury artistic persona, one that intentionally blurs the lines between life and art, truth and fiction. Dali's graphic, controversial autobiography, The Secret Life of Salvador Dali, was published in 1942, and gave him infamous status in both Europe and the United States. The text was immediately met with a great amount of interest. However, not all of the interest in Dali's written life was positive. In a 1944 essay entitled "Benefit of Clergy: Some Notes on Salvador Dali", the novelist and social theorist George Orwell opposed the public's amused curiosity towards the Catalan painter: instead he questioned the validity of Dali's written life, along with his very social position as a controversial artist. The relationship between these two texts, The Secret Life of Salvador Dali and "Benefit of Clergy", is a fascinating one, which I shall explore within this research paper. I intend to explore the ideological divide between Dali's 'surreal' ideas of self and identity and the broader Surrealist community, hence the distinction 'Surreal/ist' in the title of this research paper. It should be noted that I do not intend to analyze Salvador Dali as a physical entity; I do not wish to take the route of other scholars by speculating over his personal experience and subconscious by examining the symbolism of his paintings. Instead, in the words of David Vilaseca, I wish to consider Dali as a "textual entity" [2], a historicized, constructed figure that exists quite separately from the flesh, blood and moustache of the Catalan artist. After an analysis of these multiple facets of Salvador Dali's identity and their quite deliberate constructions, it is my hope to reach an understanding of Dali's place within art history, Surrealism, and development of the historicized life of an artist.

The Secret Life of Salvador Dali, published in New York in 1942, surfaced at an interesting time in the Catalan artist's life. Having been expelled from the French Surrealist group almost a decade earlier over conflicting political concerns (Dali had an intellectual fascination with Hitler that André Breton, as a Communist sympathizer, could not accept) [3], Dali subsequently grew in fame and notoriety 
quite separately from the artistic group, and eventually moved to the United States with his wife, Gala Dali, to avoid the Second World War. By this point, many critics of Dali's work felt that his interests were economic rather than intellectual; indeed, his autobiography could be viewed as a:

construction created for the purpose of selling a particular image of Dali to his new American public: to sell, indeed, his art as the creation of a naughty, eccentric, egotistical, but also brilliant, artist .[4]

While large portions of Dali's actions in his later life were driven by dollars (indeed, the construction of his identity to emphasize his celebrity or commodity status will be discussed in a later portion of this research paper), it would be highly incorrect to completely disregard his autobiographical writings as self-promotion.

Instead, much of Dali's autobiographical oeuvre, from texts such as The Secret Life to self-portraiture paintings like The Great Masturbator from 1929, enforce the notion of Dali's identity as unstable, polymorphous and de-centered. This idea refutes modernist, essentialist theories of the self as a distinct, closed-off concept. Rather, Dali's conception of his own being was remarkably postmodern; he seemed to repeatedly represent himself in deliberately vague, convoluted and contradictory manners. The first chapter of The Secret Life (which will be the main focus of this research paper), titled "The Anecdotic Self Portrait", highlights nineteen events across Dali's life that he deemed relevant to the development of his 'self.' Each anecdote is lushly told; his use of "overornate [5]" language almost, yet not fully, succeeds in convincing the reader of the authenticity of his stories. Instead, they remain in a bizarre place between truth and untruth: their fantastical nature undermines the assumed authenticity of the autobiographical genre, and the reader is left to ponder over the very nature of autobiography itself. One only has to pick from any story in "The Anecdotic Self Portrait” to grasp this point: the third anecdote, a 'memory' of Dali's from the age of five, tells of his cousin gifting him with a wounded bat that he had shot with a gun. The young Dali took great care of his poor pet for an afternoon, placing it in a tin pail and creating a makeshift home for the creature near his family's wash-house. However, when he returned to visit his bat the following day, he was shocked to discover that while still half-alive, the animal was now covered with a swarm of ants:

Suddenly I committed an incomprehensible act [...]. With a lightning movement I picked up the bat, crawling with ants, and lifted it to my mouth, moved by an insurmountable feeling of pity; but instead of kissing it, as I thought I was going to, I gave it such a vigorous bite with my jaws that it seemed to me I almost split it in two. Shuddering with repugnance I flung the bat into the wash-house and fled. [6]
As can be seen, this rather horrific act pushes the anecdote past a simple childhood memory to something more absurd and fantastical, and Dali's flowery language only emphasizes this notion of "concealing by revealing" [7], wherein his life becomes less accessible as it grows more incredible. Dali even references this method later in The Secret Life, as he explains his use of 'false memories': "The difference between false memories and true ones is the same as for jewels: it is always the false ones that look the most real, the most brilliant [8].” The very process of publishing The Secret Life of Salvador Dali is telling of these polymorphous, un-essentialist notions: there is no 'original' copy of The Secret Life, it is only available to the public in the version translated by Haakon M. Chevalier. Thus there is no first copy "to which one can go for the reassuring, definitive answers. Rather (by way of presenting itself as a translation which is itself an original), it undermines the very notion of the 'original' and 'proper'” [9]. It seems that all aspects of Salvador Dali's autobiographical writings twist and turn in a complicated dance: the anecdotes open themselves to the reader under the auspices of 'authenticity' and 'memory,' while simultaneously refusing us entry into Dali's fantastical and highly irrational world.

If we turn for a moment to look at Salvador Dali's painting, The Great Masturbator from 1929, these notions of the polymorphous, unstable identity find their visual equivalent. In his article, "Salvador Dali: Portrait of the Artist as (An)Other," Robert S. Lubar refers to Dali's practice of amorphous self-portraiture as one that involves a high degree of masquerade [10]: similar to the process of “concealing by revealing” [11] used in his autobiographical writings, Dali's self-portraits both hint at his 'self' while simultaneously barring the viewer from developing any concrete notions about that 'self'. Indeed, 'concreteness' is the complete antithesis to a painting such as The Great Masturbator, one where the artist's face is barely recognizable as it blends into a wide range of juxtaposed objects: a large grasshopper, a miniscule lion, a woman's profile, a man's upper thighs and covered genitalia, and of course, Dali's ubiquitous swarm of ants. These symbols impress themselves upon/sprout out of/crawl across Dali's self-image, thereby manipulating his identity and lending to its indeterminate nature.

This process of "concealing by revealing” [12] through Dali's self-portraiture also recalls the theories of the French psychoanalyst Jacques Lacan. Lacan's influence on Dali's body of work is substantial; Dali even writes of meeting the French psychoanalyst for an intellectual debate in "The Anecdotic Self Portrait." For Lacan, the exercise of portraiture was one that involved simultaneous "identification and alienation" [13], for the image that is created upon the canvas is both an aspect of the artist and an entity that exists quite separately from them: it stands as both 'me' and 'not-me.' This destabilizes the notion of the individual as concrete, stable and whole. In this sense, the 
artist/self-portrait relationship is one that "presupposes a split within the artist-sitter's identity as a unitary subject: the image viewed in the mirror [or on the canvas] is in fact an alien presence that returns its gaze to the viewing subject" [14]. Through the amorphous self-portrait motif found in paintings such as The Great Masturbator, it seems that Dali was very aware of these Lacanian ideas surrounding selfidentification and alienation. By prohibiting the viewer from fully grasping the bizarre self-image he creates, Dali both alienates the viewer while intriguing us, and conceals his 'self' while hinting at what that 'self' could become.

While Salvador Dali was clearly exploring notions of multitudinous, de-stabilized identity in his various selfrepresentations, it is evident that this was not his only motivation for painting and writing. As George Orwell writes in his 1944 critical essay of The Secret Life of Salvador Dali, entitled "Benefit of Clergy: Some Notes on Salvador Dali", much of Dali's fantastical, bizarre imagery was undoubtedly stimulated by economic concerns. While begrudgingly acknowledging Dali's status as a talented painter, Orwell uses "Benefit of Clergy" to condemn the Catalan artist's obscene imagery and 'false memories.' He understands why Dali constructs them, for as he sardonically describes, scandal and controversy always bring in good money. Referring to many instances described in The Secret Life, Orwell writes:

\begin{abstract}
Always do the thing that will shock and wound people. At five, throw a little boy off a bridge, strike an old doctor across the face with a whip and break his spectacles - or at any rate, dream about doing such things. Twenty years later, gouge the eyes out of dead donkeys with a pair of scissors. Along those lines you can always feel yourself original. And after all, it pays! It is much less dangerous than crime. [15]
\end{abstract}

In this sense, Orwell seems aware of how Dali constructs his public persona for economic gain. He does not simply dismiss The Secret Life as a text full of lies, but acknowledges Dali as "an exhibitionist and a careerist, but [...] not a fraud" [16]. This is not to say that Orwell agrees with of Dali's methods of accruing fame: it is clear that he does not only dislike the Surrealist painter, but strongly disapproves of a society within which such a man (one who proudly advertises the fact that he would bite bats in half as a child) can flourish with popularity [17]. Through these ideas, Orwell's essay develops into a discussion over the social function of celebrity, artists and scandal. He felt that artists such as Dali were allotted a certain amount of irresponsibility within society, a variant of the 'benefit of clergy', which "exempt them from the moral laws that are binding on ordinary people" [18]. Yet regardless of talent, these exceptions could not be taken too far. In what is possibly one of the most sarcastic, inflammatory and cynical comments in the entire essay, Orwell explains that:

\begin{abstract}
If Shakespeare returned to the earth to-morrow, and if it were found that his favourite recreation was raping little girls in railway carriages, we should not tell him to go ahead with it on the ground that he might write another King Lear. [19]
\end{abstract}

Orwell's critical position on Dali's autobiography and public persona is abundantly clear, yet the relationship between these two texts does not end there. Orwell was set to publish "Benefit of Clergy" in a 1944 anthology entitled the Saturday Book. However, at the last moment, the publishers removed the essay on the grounds of obscenity [20]. It is highly ironic that an 'obscene' text such as The Secret Life could be published and circulated throughout society with ease, yet an essay condemning those very obscenities would be censored for their scandalous nature. This incident is far more indicative of Dali's place within Western society than any comment made in "Benefit of Clergy"; it is clear that Dali had constructed a public position for himself through which provoking and scandalous acts were expected, if not encouraged. George Orwell, on the other hand, as a novelist and social theorist, did not fall into the same category.

Thus Dali did not only construct his identity to reflect de-centered, un-essentialist notions, he was also concerned with his publicity and self-promotion. This is especially clear when considering Dali's relationship with his American audience. In his article "'An Amusing Lack of Logic:' Surrealism and Popular Entertainment”, Keith L. Eggener compares the reception of Surrealism in Europe and the United States. In particular, American supporters of the artistic movement seemed to look towards artists such as Dali for amusement as opposed to political or intellectual enrichment: "drained of its political content and reconstituted as entertainment, Surrealism was frequently cast as the close cousin of cartoons and popular cinema" [21]. This climate provided the perfect opportunity for Dali to reassert his celebrity status. To achieve this goal, Dali enthusiastically fashioned his public persona according to ruling stereotypes about the 'genius' artist, stereotypes which Robert Hughes divides into two categories: "Painter as Old Master (Raphael, Rubens); [...] [and] Artist as Freak (Rimbaud, van Gogh). Dali's public image contrived to give a tacky, vivid caricature of both while fulfilling neither" [22]. Dali also encouraged his American celebrity status through the blatant repetition of his common visual themes: he quite literally turned himself into a trademark and promoted a type of brand loyalty regarding his artistic output [23]. Dalinian symbols such as the soft watches, swarming ants, crutches and burning giraffes would have been considered controversial and outrageous in the early 1930s. Yet by the time The Secret Life was published in 1942; these bizarre images were familiar and easily consumed by the American public. Yet it was Dali's own image, his wide, probing eyes and his iconic moustache, that became more recognizable as a commodity than any individual piece of his artistic oeuvre. His face could be found everywhere in the United States, from the 
1936 cover of Time Magazine to his appearance on an American game show program [24]. Dali not only reinforced the notion of his own 'self' as a commodity, but also lent his infamous status to the advertising of other commodities. In one such French television advertisement for Lanvin Chocolate, which aired in 1968, Dali stares at the audience with his typical wide-eyed look and takes a large bite from the Lanvin chocolate bar in his hands. Suddenly, his iconic moustache magically turns upward. "I am mad," he shrieks, “for Lanvin Chocolate!” [25] By capitalizing on familiar tropes of Dali's public identity, (his presumed 'madness' and his waxed moustache), both Dali himself and the Lanvin Chocolate Company successfully promoted their wares to the television audience. Thus, through his shameless selfpromotion and commodification of his own image, our Catalan painter seemed very aware of his public identity and strove to ensure that his audience would remember his name: Dali the entertainer, madman, artist, trademark.

While Dali's celebrity image cannot be denied, his identity as a member of the Surrealist collective is quite precarious. In fact, it could be said that this aspect of the Catalan painter is best defined as 'Surreal/ist,' a distinction that separates Dali's own surreal aims from those of the French Surrealist group. Both Dali's philosophical perspectives and fantastical public life were orchestrated independently of his artistic colleagues, therefore this divided term acts as the most appropriate method to describe his relationship with the Surrealist community. As mentioned earlier, André Breton formally ejected Dali from the Surrealist group in 1934. The Surrealists, who had been steadily growing more and more left wing in political persuasion, were alarmed by Dali's intellectual and aesthetic fascination with Adolf Hitler [26]. On February 5 ${ }^{\text {th }}, 1934$, while giving a speech on the subject to his fellow Surrealists, Dali was interrupted by a sudden cry from Breton: "Do you intend to bore us much longer with this damn nonsense about Hitler?" [27] While the other Surrealists were growing concerned about Dali's political motivations, David Vilaseca views this situation from a different angle: by refusing to tone down his intellectual curiosities, regardless of the political climate, "Dali thus appeared to be more transgressive, more Surrealist than the Surrealists themselves [28]." This could easily be the case, yet the Surrealist collective was also growing exasperated by Dali's flagrant methods of self-promotion. By coining the nickname 'Avida Dollars,' an anagram of 'Salvador Dali' [29], André Breton was undoubtedly hinting at his disapproval for Dali's fame, wealth and over-the-top public persona. Yet regardless of which route one takes (Dali as transgressor or Dali as selfpromoter), the Catalan painter's concerns were indeed quite separate from those of the Surrealist collective, and his selffashioned identity within the frame of the artistic movement can best be described as 'Surreal/ist' in motivation.

If nothing else can be concretely declared about Salvador Dali, it remains clear that his public identity was a highly constructed, polymorphous creation. Dali presented himself to us in a number of ways: as a madman, an entertainer, a commodity, and a Surreal/ist. In reference to what may be his most infamous quotation: "The difference between a madman and me is that I am not mad” [30], it becomes obvious that Dali's madness was controlled, calculated and performative. Through a vast array of media, from The Secret Life of Salvador Dali, to The Great Masturbator, to a thirty-second commercial for a French chocolate bar, Dali has constructed himself for us, not as a unified, concrete subject, but as an entity that is capable of transformation and movement. George Orwell may have been offended by Dali's blurring of truth and fiction in The Secret Life, yet this remains integral to Dali's process of selffashioning. His lived life was no longer relevant; instead it is his historicized, surreal life that will continue in his name. In the introduction to The Secret Life, Salvador Dali wrote, "One thing, at least, is certain: everything, absolutely everything, that I shall say here is entirely and exclusively my fault” [31]. That much (if nothing else) is perfectly true: every aspect of his identity was his own construction. In the end, we just have Dali to blame.

\section{REFERENCES}

1. Salvador Dali, The Secret Life of Salvador Dali, trans. Haakon M. Chevalier (New York: Dover Publications Inc., 1993): 1.

2. David Vilaseca, The Apocryphal Subject: Masochism, Identification, and Paranoia in Salvador Dali's Autobiographical Writings (New York: Peter Lang Publishing, 1995): 6.

3. Ibid., p. 213.

4. Haim Finkelstein, Salvador Dali's Art and Writing, 1927-1942: The Metamorphoses of Narcissus (Cambridge: Cambridge University Press, 1996): 256.

5. Ibid., p. 256.

6. Dali, The Secret Life, p. 14

7. Finkelstein, Salvador Dali's Art and Writing, p. 256.

8. Dali, The Secret Life, p. 38.

9. Vilaseca, The Apocryphal Subject, p. 8.

10. Robert S. Lubar, "Salvador Dali: Portrait of the Artist as (An)Other," in Dawn Ades and Fiona Bradley, eds., Salvador Dali, A Mythology (London: Tate Gallery Publishing Limited, 1998): p. 106.

11. Finkelstein, Salvador Dali's Art and Writing, p. 256.

12. Ibid., 256.

13. Lubar, 108.

14. Ibid., p.111.

15. George Orwell, "Benefit of Clergy: Some Notes on Salvador Dali,” in George Orwell, ed. Dickens, Dali and Others (New York: Harcourt, Brace and World, Inc., 1946): pp. 182-183.

16. Ibid., p. 175.

17. Ibid., p. 176. 
18. Ibid., p. 177.

19. Ibid., p. 178.

20. George Orwell, "Introductory Note," in George Orwell, ed., Dickens, Dali and Others (New York: Harcourt, Brace and World, Inc., 1946).

21. Keith L. Eggener, "'An Amusing Lack of Logic:' Surrealism and Popular Entertainment," American Art 7. No. 4 (Autumn, 1993): p. 32.

22. Robert Hughes, The Shock of the New (New York: Alfred A. Knopf, 1981): 237.

23. Eggener, “'An Amusing Lack of Logic,”” p. 42.

24. Ibid., p. 43.
25. Author's own translation. "Salvador Dali - Lanvin Chocolate," Posted by internet user: espermascontracacas, 26 November 2005, date of access: 25 March 2009 Youtube. http://www.youtube.com/watch?v=rK4Bh_arF-E.

26. Vilaseca, The Apocryphal Subject, p. 213.

27. Quoted in Ibid., p. 213.

28. Ibid., p. 214.

29. Eggener, “"An Amusing Lack of Logic,” " p. 41.

30. Quoted in Robert Hughes, The Shock of the New, p. 237.

31. Dali, The Secret Life, p. 6. 